ISSN 1816-6075 (Print), 1818-0523 (Online)

Journal of System and Management Sciences

Vol. 9 (2019) No. 3, pp. 26-44

DOI:10.33168/JSMS.2019.0302

\title{
Assessment of Organizational Performance of Private Manufacturing Companies: The Impact of Supply Chain Management Responsiveness
}

\author{
Attamah Joseph Ikechukwu \\ Department of Management, University in Kisangani, Democratic Republic of the \\ Congo \\ sinbazhu@163.com
}

\begin{abstract}
This paper analysis the impact of supply chain management responsiveness on organizational performance in some private manufacturing companies in Democratic Republic of the Congo. The paper considered the successes recorded by multinationals with a paradigm shift from sole autonomous business entities to collaborative team in supply chain management. A new performance strategic twists which most DR Congo manufacturing organizations is yet to embrace. The purposes were to examine the effect of lean and agile strategies on cost reduction and productivity. Also, revealed the relationship between PME responsiveness to customers demand and level of inventory in the warehouse. Two research questions and hypotheses were raised. A sample size of 30 using $G^{*}$ Power version 3.1.9.2 calculation technique was used to derive the company size while Freud and Williams statistical tool was used for the population of 2057 which gave a sample size of 649 top management staff across South East selected branches of MAN . Fisher's Extract, Multiple Regression, Ttest among others formed the analytical tools. The findings revealed a significant association between effective management of Supply Chain through the use of lean strategy reduced waste of time, resources and increased productivity. Also, responsiveness to customer's demands is significantly associated with increase in sales and low inventory level in warehouse. Some recommendations also proposed in the end of this study based on the findings and their characteristics.
\end{abstract}

Keywords: effect, supply chain, management, performance and organization. 


\section{Introduction}

One of the most significant paradigm shifts in modern business management is that individual businesses no longer compete as solely autonomous entities, rather as supply chain. Business management has entered into the era of inter network competition (Drucker, 1998). Supply chain Management is the management of a network of all the entities and activities involved in delivering a product from the suppliers of raw materials through to the customers. It also includes sourcing of raw materials and parts, manufacturing and assembly, warehousing and inventory tracking, order entry and order management, distribution across all channels, delivering to the customers and the information system needed to monitor all these activities (Vitasck,2010; Lambert, 2010; Quinn,1998).

Companies no longer compete solely as independent entities with each other, rather as supply chains (Lambert et al, 2000). This is because as Lumnius et al (2000) observe that firms do not effectively compete in isolation of their suppliers and other entities in the supply chain, they are aware of the benefits of collaborative relationship within and beyond their own organization. Historically, most companies have been focusing on the integration of logistic activities within the organization which includes: inbound, and outbound, transportation, warehousing, material handling, order fulfilment, logistic network, design, inventory and supply/demand planning (Council of Supply Chain Management Professional, 2013).

The increasing demand and ever changing customer preferences have forced companies to focus on their core competencies and allow other supply chain partners carry out large part of the work more than before (Lambert, 2008). This increased outsourcing and the complex customer demand have created challenges for companies and they have realized that only coordinating the internal processes in the organization is insufficient to handle the problem (Janyara, Vickery and Drage, 2010). This made supply chain management inevitable. SCM breaks down the walls around firms by creating a relationship with the partners in a more cooperative way, that will provide incentives for suppliers to merge their "learning curves' (that is, share findings about how to make parts, better, cheaper, faster and with less effort) with customers and other suppliers (Lamning, 1996). He further states that SCM tries to exploit expertise and agile responsiveness wherever it lies in the chain and this cooperative supply chain relationship he calls, "beyond partnership.

The ultimate performance success of a single firm depends on the management's ability to integrate the company's intricate network of business relationships to the supply chain (Drucker, 1998). Jan (2001) asserts that the main objective of supply chain management is to manage the whole supply chain and its operations efficiently and effectively by coordinating and integrating all the 
activities that are executed by different departments and external partners in the supply chain.

Performance is no longer determined by the decisions and actions that occur in individual firms, because the execution of the activities of all members involved, contribute to the overall results of supply chain (Nasland and Williamson, 2010). The performance depends on the seamless co- ordination of all supply chain stakeholders to ensure attainment of the desirable outcomes. Habib (2011) observes that evidence has shown that centralized decision making confers the chain with opportunities to reduce the strategic misalignment of partners' capabilities, practices and interaction policies required by the companies to be well coordinated to achieve supply chain objectives effectively and efficiently.

Supply Chain Management approach has been accepted as a proven managerial approach to achieve sustainable profits and growth through focusing on the whole supply chain management process to deliver the right products or services in the right quantity to the right place at the right time and with the maximum benefits (Nieto, 2011). Business managers in western nations have seen SCM as a palliative to their numerous business challenges. They have eagerly implemented important concepts that have emerged from the many published papers on supply chain management, leanness, agility among others to achieve the combined benefits of improved cost, flexibility, quick delivery [responsiveness] and quality (Hayes and Wheelwright, 1984).

In Western economies like United States of America, United Kingdom, Germany, South Korea, Singapore, among other western nations, private enterprises account for as high as $64 \%$ of industrial employment, industrial production and full capacity utilization of their production capacity, but the comparable figure in DR Congo is as low as 31\% (Onugu, 2005). Pacrarisi and Ya-Huihsu (2013) contend that PMEs as part of private sector need to work together in order to achieve better operational performance in terms of flexibility, high product quality and low cost, which will yield higher organizational performance in terms of employment generation, infrastructural development among others. Against this backdrop, this study seeks to examine the effect of supply chain management responsiveness on the organizational performance of selected Private Manufacturing Enterprises in DR Congo. 


\section{Statement of problem}

The global business environment is so turbulent that products` life cycle shrinks easily and new ones are introduced. This makes flexibility and responsiveness to customers`demand inevitable.

Manufacturers keep trying different business strategies to remain competitive. Private enterprises in developed nations of the world have found supply chain management approach a veritable approach to meet with the global competition. Such private enterprises like Walmart retail shops, Georgia-Pacific Corp, leading manufacturers of building materials in North America, Japanese Toyota manufacturing industries, Dell, manufacturers of appliances, Whirlpool, HewlettPackard, Shoprite, Games and a host of other firms have used supply chain as a strategic weapon to gain advantage over peers.

They have achieved sustained profit and growth by delivering the right product and service in the right quantity to the right customers at the right time and right place with the maximum benefits translated into cost decrease, lower inventory level, shorter lead-time, lessened demand uncertainties and improved product quality. These firms produce in small batches to be responsive to customers ever changing demands and to enjoy high market share. They account for as high as $64 \%$ of industrial employment, industrial production, and even full capacity utilization of their machines.

Unfortunately in DR Congo, private business sector of the economy has been undergoing turbulent times especially in the staggering face of recession. They have not been occupying their rightful place as catalysts for economic development and infrastructural provisions like their counter parts in developed economies. They cannot compete effectively in the world market as key players in terms of selling their products but as market for other nations`goods. Among the numerous reasons envisaged is the adoption of the archaic and traditional approach of mass-production to meet a schedule or forecast without a defined market. Their competition being at individual or brand versus brand level, poor identification and integration to their key business partners especially the suppliers of raw materials and customers. This failure hinders the effective flow of raw materials and relevant information about the market and other competitors. In fact this poor integration and collaboration with partners has caused untold wastage of raw materials and other goods especially the recent tomatoes in surge into the DR Congo market between January-March, 2016. The quantity wasted was more than the quantity preserved. This wastage would have been avoided if there was effective integration with the manufacturers of tinned tomatoes. Worse still the standard organization of DR Congo (SON) and other agencies that see to the quality of goods produced or imported into DR Congo are ineffective giving room for DR Congo market to be a dumping ground for substandard goods that are cheaper than made- in-DR Congo goods, for the vulnerable poor masses. The effect of the condition on the economy is so grave and adverse; 
the local manufacturers are out of the market, leaving the economy impoverished. We can observe that there is high mortality rate of these firms in this sector that many do not survive beyond two- five years of their inception. Many of the numerous firms around us can attest to this fact. This untimely extinction, affects adversely the individual owners in particular and the economy in general. The loans borrowed are not repaid, the staff of the organizations laid off, increasing the unemployment rate and the terrible consequences on the economy.

Again, the noninvolvement of suppliers of raw materials and customers at the early stage of product design and development leads to the production of wrong mix of products that are dumped in different distribution channels. For DR Congo PMEs to compete effectively in the global market as key players, their products must be competitive in quality, low cost, trendy (responsive to current demand) and always available. It is of serious note that these indices of excellence and competitiveness in business arena are associated with supply chain management approach. Few studies done in this area in DR Congo have their concentration in South-West, and none in DR Congo. To fill this gap therefore, this study is slated to examine the effect of supply chain management- responsiveness on organizational performance in DR Congo.

\section{Objectives of the study}

- Examine the effect of lean and agile strategies on cost reduction and productivity of the PMEs.

- Determine the relationship between PMEs responsiveness to customers demand, and level of inventory in the warehouses.

\section{Research Questions.}

- To what extent do lean and agile strategies affect cost reduction and productivity of the PMEs?

- How does responsiveness to customers' demands relate to level of inventory in warehouses?

\section{Research Hypotheses}

- The use of lean and agile strategies significantly reduces cost and increase productivity in PMEs.

- Responsiveness to the changing demand of the customers relates positively to the low inventory level.

\section{Literature Review}

The Concept of Supply Chain (SC) Supply chain is a network of organizations, involved through upstream and downstream linkages in the different processes and activities that produce value in the form of products and services in the hands of the ultimate customers (Christopher, 1994).The chain comprises the suppliers- 
manufactures-distributors- retailers - customers (Chopra and Meindl, 2001). The basic chain looks like a pipe but in reality the chain looks more like an uprooted tree than a pipe in structure because it is linked with partners horizontally and vertically (Lambert and Cooper, 2000). The literature relating to the SC is both "patchy and unconnected, this adds to the "ataxia around the explanation (Harland 1999; Giannakis and Croom, 2004).

\subsection{Supply chain network structure}

Supply chain management encompasses the planning and management of all activities involved in sourcing and procurement, conversion, demand creation and fulfilment of all logistic management activities. It also includes the co-ordination and collaboration with channel partners which can be suppliers, intermediaries, third party service providers and customers (Vitasck, 2010). In essence SCM integrates supply and demand management within and across companies which continues to change and evolve to suit the needs of the growing global supply chain.

In the management of supply chain, not all the branches and roots are included, because not all links can be closely coordinated and integrated. The closeness and relationships at different points of the chain differ. The management chooses the level of partnership appropriate for a particular supply chain link (Lambert et al, 1996).The most appropriate relationship is the one that best fits the specific set of circumstances (Lambert et al, 1993). The part of the supply chain that deserves management attention must be weighed against firm's capabilities and the importance to the firm (Lambert et al, 2000).

\subsection{Concept of lean}

The Lean concept is the emphasis on the use of continuous improvement activities that focus on eliminating all non-value adding activities along the supply chain, for example reduce the time to set up machinery and enhance performance system, this production strategy encourages production in small batches to meet changing demand, reduce mass production that are not necessary, reduce costs, maintain flexibility and increase profits. This lean production strategy is flexible and responsive to customers demand which affects design timing and distribution of the goods (Vanderembse et al, 2006).

\subsection{The concept of agility}

The term 'agile' means the ability to think fast and use a clearer method for maximum flexibility. An agile organization should be able to respond to possible changes that may occur in the organization. The major feature of agile organization is flexibility. (Aganwal et al, 2007). This concept can be traced to flexible manufacturing system which moves from automation towards the ability to create rapid changes such as reducing start-up time and faster reaction to changes in 
product mix or volume. The agility includes; speed, flexibility, competence and accountability (Gitaninia et al, 2011).

\subsection{Comparing lean and agile pattern}

Both concepts demand high level of product quality, minimum lead-time (from time a customer raises request for a product or service till it is delivered). If a supply chain has long end-to-end lead-time, it will be difficult to respond quickly enough to exploit market place demand. Effective engineering of cycle time reduction always leads to significant bottom line improvements in manufacturing costs and productivity (Towil, 1996). Lead-time needs to be minimized, in lean manufacturing, excess time is a waste and leanness calls for the elimination of such wastes.

While quick response to customers is for agility, cost and sales price is linked to leanness. When the total cycle-time compression is effectively implemented, it creates sufficient condition for achieving high performance in the organization (Towil, 1996). The summary of lean and agile patterns in customer value perspective is in - quality, price, delivery time and service level. Naylor et al (1999) further propose the combination of the two paradigms (lean x agile) into "legality stating that they both are complementary within a correct supply chain strategy.

\subsection{The concept of organizational performance (op)}

The 'raison d'être' of any commercial firm is continuity and profit generation (Onunwa, 2008). This parameter (profitability) only is insufficient to measure the performance of an organization knowing very well that there are many interested parties in the organization, ranging from shareholders to employees, customers, and then communities that host the organization. Performance therefore should include both profitable (finance) and nonprofit able measures like the market share, customer satisfaction, employee satisfaction and good governance among others (ibid). Organizational performance is the ability of an organization to use its resources efficiently and effectively to produce outputs that meet or are consistent with the goals or objectives and relevant to its users (Peterson, Cusber and Wilks, 2003).

\subsection{Measurement of performance}

The pressure on organization for accountability and performance has raised the need for performance measurement. Performance measurement is observed to have gone beyond short term level to long- term value, creating activities such as customer service, quality of internal process and organizational learning (Kaplan \& Norton, 1996).

To measure the performance of a firm or network of firms, the following metrics are considered: Net income, revenue growth, productivity, customer 
satisfaction and employee retention representing the outcomes of performance but not the causes (onunwa, 2008).

Supply Chain Management Model Supply Chain Operations Reference (SCOR) Model, the world's leading supply chain framework was used in this study because it is a management tool used to address, improve and communicate supply chain management decisions within a company responsively and with suppliers and customers of other companies. The model increases the speed of system implementation and support organizational learning goals which improves inventory turns. This model was developed by Supply Chain Council (SCC) and AMR Research in 1996. According to them, SCOR is used to identify measures, reorganize and improve supply chain processes through a cyclical process that includes: capturing the configuration of supply chain, measuring the performance of the supply chain and comparing against internal and external industry goal and realigning supply chain processes and best practices to fulfil unachieved or changing business objectives. The SCOR model is diagrammatically represented as below:

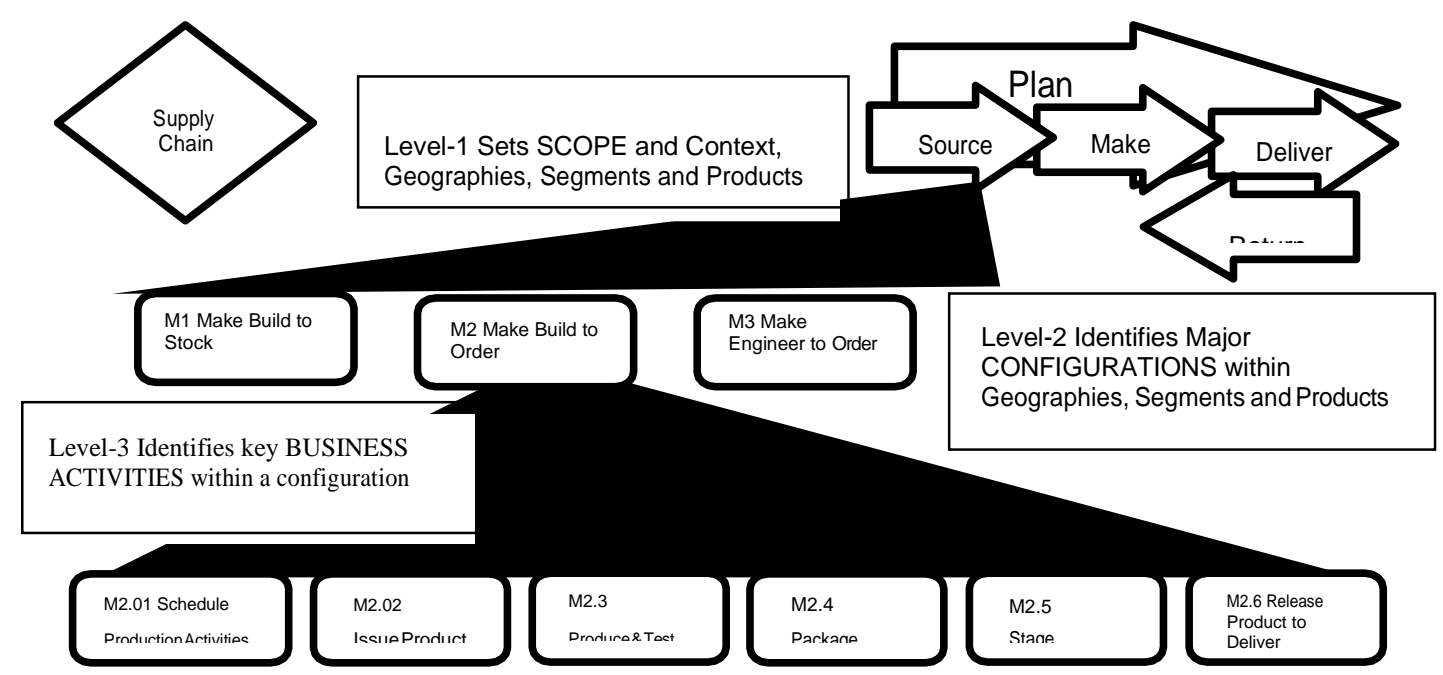

Fig. 1: SCOR framework levels

These processes of plan, source, make and deliver of the SCOR model give a continuous chain of activity in levels throughout the company's internal operations and potentially across the whole inter-organizational supply chain. It is possible to contend that the framework includes a high level of planning process which provides balance of aggregate demand and supply to develop a course of action that best meets the requirements of the processes of source, make and deliver (Lambert et al, 2005).

\section{Methodology}


The study adopted a survey research design. The population drawn from the branches was 184 made up of Manufacturing Association of DR Congo (MAN) branches in Anambra and Imo comprising of 147 and 37 top graded manufacturing companies. A sample size of thirty (30) companies using G*Power version 3.1.9.2 sample size calculator at the effect size of 0.25 that gave a good representative of the entire population of 2057 was obtained. The effect size is a measure of the level of prevalence; awareness or occurrence previously reported or guest mated (Nna, 2016). The effect size was based on $61 \%$ level of awareness of SCM reported South-Western DR Congo. Systematic random sampling technique was used in selecting this number from the list of companies registered with Manufacturers Association of DR Congo (MAN) which formed the population at the interval of 6 to cover the five states. Cronbach Alpha at 0.89 levels was used in establishing the reliability of the measuring scale, while the $95 \%$ confidence level was adopted and tested at $5 \%$ level of significance and the stated hypotheses had a maximum acceptable risk of making a type one error (that is, rejecting the null hypotheses (Ho) when it should have been otherwise) is 5\%. Fisher's exact value statistical tool was used to test the socio- demographics of the PMEs respondents sampled and other hypotheses formulated in the study. At the inferential level of analyses, multiple regression analysis and t-test were used to test the relationship between the two variables (dependent and independent); also hierarchical cluster analysis was done to show the closeness in relationship. The results were reported diagrammatically for clearer under- standing. 
Table 1: What are the effects of lean and agile strategies on cost reduction of private manufacturing enterprises?

\begin{tabular}{|c|c|c|c|c|}
\hline $\begin{array}{l}\text { To what extent do lean and agile strategies } \\
\text { affect cost reduction and productivity of the } \\
\text { PMEs }\end{array}$ & SAA & ASD & UD & Total \\
\hline & 54 & 32 & 1 & \\
\hline $\begin{array}{l}\text { The continuous improvement through lean } \\
\text { strategy eliminates non- value adding activities } \\
\text { and reduces cost in the organization }\end{array}$ & $\begin{array}{c}498 \\
98.2 \%\end{array}$ & $\begin{array}{c}9 \\
1.8 \%\end{array}$ & - & 507 \\
\hline $\begin{array}{l}\text { The lean and agile strategies encourage } \\
\text { production in small batches to meet changing } \\
\text { demand; this reduces mass production that ties } \\
\text { working capital to the dumped goods and } \\
\text { increases cost of the goods. }\end{array}$ & $\begin{array}{c}500 \\
98.6 \%\end{array}$ & $\begin{array}{c}6 \\
1.2 \%\end{array}$ & $\begin{array}{c}1 \\
0.2 \%\end{array}$ & 507 \\
\hline $\begin{array}{l}\text { Agile strategy works with current information } \\
\text { to respond to changes in the market and avert } \\
\text { possible increase in cost. A company that uses } \\
\text { this quick action enjoys reduced cost of } \\
\text { production in the organization }\end{array}$ & $\begin{array}{c}504 \\
99.4 \%\end{array}$ & $\begin{array}{c}3 \\
0.6 \%\end{array}$ & - & 507 \\
\hline $\begin{array}{l}\text { Agile strategy encourages flexibility and } \\
\text { increases speed by linking to autonomous } \\
\text { companies. These linkages reduce transaction } \\
\text { cost, handling cost (total cost) in the } \\
\text { organization }\end{array}$ & $\begin{array}{c}507 \\
100 \%\end{array}$ & - & - & 507 \\
\hline $\begin{array}{l}\text { When a manufacturing enterprise enjoys a } \\
\text { larger share of the market, because the price } \\
\text { of the goods is competitive enough, it expands } \\
\text { the frontiers (creating new branches and } \\
\text { introducing new products) this increases } \\
\text { productivity }\end{array}$ & $\begin{array}{c}485 \\
95.7 \%\end{array}$ & $\begin{array}{c}20 \\
3.9 \%\end{array}$ & $\begin{array}{c}2 \\
0.4 \%\end{array}$ & 507 \\
\hline Grand total & 2494 & 38 & 3 & 2535 \\
\hline Percentage & $98.4 \%$ & 1.5 & 0.1 & 100 \\
\hline
\end{tabular}

\subsection{Interpretation}

In table 1.0, five questions were designed to give answers to the effect of lean and agile strategies on cost reduction of private manufacturing enterprises. The result of the analysis based on the cumulative response showed the expected response frequency of 2535 , while the observed response of strongly agree/agree was $2494(98.4 \%) 38(1.5 \%)$ of strongly disagree and disagree and $3(0.1 \%)$ rate of 
undecided. This implied that $98.4 \%$ of the respondents agreed that the use of lean and agile strategies reduced cost while $1.5 \%$ disagreed to the assertion, only $0.1 \%$ were indifferent.

\subsection{Test of hypothesis one}

Ho: Lean and agile strategies cost reduction of PMEs does not significantly increase productivity.

Hi: lean and agile strategies cost reduction of PMEs significantly increases productivity.

Test of significance: Fisher's exact value test at 0.05 alpha was used to test for statistical significance association $=29.82 \mathrm{P}$

Table 2: Multiple regression report descriptive statistics

\begin{tabular}{|c|c|c|c|c|c|}
\hline Variable & Count & Mean & Std deviation & Minimum & Maximum \\
\hline $\begin{array}{c}\text { Lean and agile of PMEs significantly } \\
\text { increases productivity }\end{array}$ & 53 & 4,356604 & 0.5468414 & 3.4 & 5 \\
\hline
\end{tabular}

Table 3: Regression coefficients T-Test

\begin{tabular}{|c|c|c|c|c|c|c|c|}
\hline $\begin{array}{c}\text { Independent } \\
\text { variable }\end{array}$ & $\begin{array}{c}\text { Regression } \\
\text { coefficient }\end{array}$ & Std. Error & $\begin{array}{c}\text { Std. } \\
\text { coefficient }\end{array}$ & $\begin{array}{c}\text { T-statistics To } \\
\text { test H0 : } \boldsymbol{\beta}(\mathbf{1})=\mathbf{0}\end{array}$ & $\begin{array}{c}\text { Prob. } \\
\text { level }\end{array}$ & $\begin{array}{c}\text { Reject H0: } \\
\text { at 5\% }\end{array}$ & $\begin{array}{c}\text { Power } \\
\text { test at } \\
\mathbf{5 \%}\end{array}$ \\
\hline Lean and agile & 1 & 0 & 1.000 & & & & \\
\hline
\end{tabular}

Note: The T-value used to calculate the confidence unit was 213.

Table 4: Analysis of variance detail

\begin{tabular}{|c|c|c|c|c|c|c|c|}
\hline Source & DF & R2 & $\begin{array}{c}\text { Sum of } \\
\text { squares }\end{array}$ & Mean square & F-ratio & Prob. level & Power at (5\%) \\
\hline Intercept 1 & 1 & & 1091.779 & 1091.779 & & & \\
Model & 4 & 1.000 & 8.273208 & 1.378868 & 0.000 & 1.000 & 0.0500 \\
Question 1 & 1 & 0.000 & 0 & 0 & 0 & & \\
Normality tests & 1.0000 & 0.000 & 8.273208 & 0.1591001 & 0 & & \\
\hline
\end{tabular}

\subsection{Interpretation}

Fisher's exact value test $=348.6, \mathrm{P}<0.05$ the regression sum of squares $(8.273208)$ is greater than the mean squares (1.378863).This means that the relationship between the two variables is significant. Also the value of F-Ratio (0.000) is less than 0.0500 which indicates that the variation explained by the model is not due to chance. 
The R2 (regression coefficient) $=1$ shows that there is significant positive relationship between PMEs agile and lean strategies and cost reduction in the organizations which is also shown with t-test value 1.0000. Therefore the null hypothesis should be rejected and the alternate hypothesis accepted.

\subsection{Research question}

Table 5: How does responsiveness to customers' demand relate to patronage (sales) and level of inventory in warehouses?

\begin{tabular}{|c|c|c|c|c|}
\hline $\begin{array}{l}\text { How does responsiveness to customers demands } \\
\text { relate patronage (sales) and level of inventory in } \\
\text { warehouses }\end{array}$ & VHE/HE & VLoE/LE & UD & Total \\
\hline $\begin{array}{l}\text { When the manufacturers are sensitive to meet the } \\
\text { ever changing demands of the customers, there is } \\
\text { high level of patronage (sales) by the customers. }\end{array}$ & $\begin{array}{c}503 \\
(99.2 \%)\end{array}$ & $\begin{array}{l}<4 \\
0.8\end{array}$ & - & 507 \\
\hline $\begin{array}{c}\text { The use of lean and agile strategies in production } \\
\text { Processes, remove delays, wastages and increase } \\
\text { acceptability patronage of the goods produced } \\
\text { because they are in vogue or trendy. }\end{array}$ & $(92.5 \%)$ & 6.5 & 1.0 & 507 \\
\hline $\begin{array}{l}\text { When customers are brought early into product } \\
\text { development process their demands are known and } \\
\text { production carried out to meet that demand which } \\
\text { ensures increase in sales }\end{array}$ & $\begin{array}{c}435 \\
(85.8 \%)\end{array}$ & $\begin{array}{l}50 \\
9.9\end{array}$ & $\begin{array}{l}22 \\
4.3\end{array}$ & 507 \\
\hline $\begin{array}{l}\text { production in small batches to respond to ever } \\
\text { changing demands of customers reduces inventory } \\
\text { level in distribution channels }\end{array}$ & $\begin{array}{c}505 \\
(99.6 \%)\end{array}$ & $\begin{array}{c}2 \\
2.4\end{array}$ & - & 507 \\
\hline $\begin{array}{l}\text { Mass production or production to meet a schedule or } \\
\text { forecast (make -to-stock) increases inventory level in } \\
\text { warehouses. High inventory level in warehouses is a } \\
\text { waste to manufacturers because of tied up capital and } \\
\text { goods becoming obsolete over time. }\end{array}$ & $\begin{array}{c}488 \\
(96.3 \%)\end{array}$ & 12 & $\begin{array}{c}7 \\
1.4\end{array}$ & 507 \\
\hline Grand total & 2402 & 101 & 34 & 2535 \\
\hline Percentage & $94.8 \%$ & $4 \%$ & $1.3 \%$ & 100 \\
\hline
\end{tabular}

\subsection{Interpretation}

Table 3 the five (5) statements of fact were given in the questionnaire to examine how responsiveness to customers demand relates to patronage (sales) and the level of inventory in the warehouses. The result of the analysis based on cumulative response shows the expected response frequency of 2535. The observed response rate of strongly agree/ agree (VHE/ HE) of 2400(94.7\%), 101(4\%) of strongly disagree/disagree (VLE/LE) and $34(1.3 \%)$ rate of undecided. This reveals that 
$94.7 \%$ of the respondents are in agreement that when organizations respond to the changes in demands of the customers, it increases patronage (sales) and reduces the inventory level in the warehouses

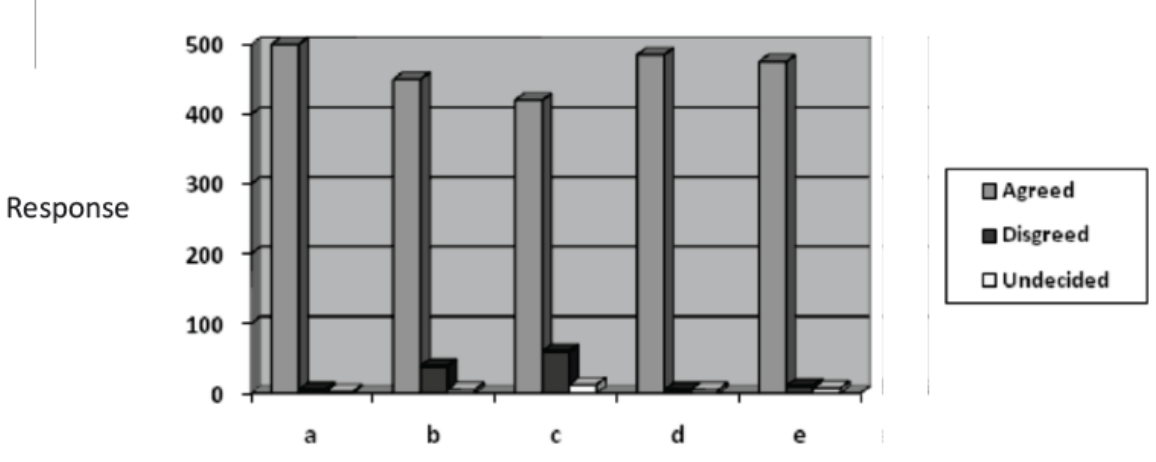

Fig. 2: Respondents statistics

\subsection{Testing of hypothesis two}

$\mathrm{H}_{\mathrm{o}}$ : Responsiveness to customers' demands does not lead to increase in sales and low inventory in distribution channels.

$\mathrm{H}_{\mathrm{i}}$ : Responsiveness to customers' demands leads to increase in sales and low inventory in distribution channels.

Tests of significance: Fishers' exact value test was used to test for statistical significant association $=133.6, \mathrm{P}<0.05$.

Table 6: Multiple regression report

\begin{tabular}{|c|c|c|c|c|c|}
\hline Variable & Count & Mean & $\begin{array}{c}\text { Std. } \\
\text { Deviation }\end{array}$ & Minimum & Maximum \\
\hline $\begin{array}{c}\text { Responsiveness to customers' } \\
\text { demands leads to increase in sales } \\
\text { and low inventory in distribution } \\
\text { channels }\end{array}$ & 53 & 4.151132 & 0.7340893 & 1.83 & 5 \\
\hline
\end{tabular}


Table 7: Regression coefficients t-test

\begin{tabular}{|c|c|c|c|c|c|c|c|}
\hline $\begin{array}{c}\text { Independent } \\
\text { Variable }\end{array}$ & $\begin{array}{l}\text { Regression } \\
\text { coefficient }\end{array}$ & $\begin{array}{c}\text { Standard } \\
\text { error }\end{array}$ & $\begin{array}{c}\text { Standardized } \\
\text { coefficient }\end{array}$ & $\begin{array}{c}\text { t-statistic to } \\
\text { test H0: } \beta \text { (1) } \\
=0\end{array}$ & $\begin{array}{l}\text { Prob. } \\
\text { level }\end{array}$ & $\begin{array}{c}\text { Reject } \\
\text { H0:at 5\% }\end{array}$ & $\begin{array}{c}\text { Power } \\
\text { test at 5\% }\end{array}$ \\
\hline $\begin{array}{l}\text { Responsiveness } \\
\text { to customers' } \\
\text { demands }\end{array}$ & 1 & 0 & 1.0000 & & & & \\
\hline
\end{tabular}

Table 8: Analysis of variance detail

\begin{tabular}{|c|c|c|c|c|c|c|c|}
\hline Source & Df & R2 & $\begin{array}{c}\text { Sum of } \\
\text { Square }\end{array}$ & $\begin{array}{c}\text { Mean } \\
\text { squares }\end{array}$ & F-ratio & Prob level & $\begin{array}{c}\text { Power at } \\
\text { (5\%) }\end{array}$ \\
\hline Intercept & 1 & & 1091.779 & 1091.779 & & & \\
Model & 5 & 1.00 & 8.273208 & 1.378868 & 0.000 & 1.000 & 0.0500 \\
Questions & 1 & 0.000 & 0 & & 0 & & \\
\hline
\end{tabular}

\subsection{Interpretation:}

Fisher's exact value test was used to test for the statistical significant association $=133.6, \mathrm{P}<0.05$, there is significant association between responsiveness to customers demand, increase in sales and low inventory in distribution channels.

The regression sum of squares (8.273208) is greater than the mean square (1.378863), which means there is significant relationship between the two variables.

Also the value f-ratio (0.000) is less than 0.0500 which indicates that the variation explained by the model is not due to chance. The R2 (regression coefficient) $=1$ shows that there is significant positive relationship between responsiveness to customers demand, increase in sales and low inventory in distribution channels. Therefore the null hypothesis should be rejected and the alternate hypothesis is accepted.

\section{Discussion of Results}

\subsection{Objective one}

To examine the extent of lean and agile strategies on cost reduction of the PMEs In analyzing the research question, the result showed that $98.4 \%$ of the respondents agreed that effective supply chain management produced cost reduction through the use of lean and agile strategies. The test of hypothesis-2 using Fisher's exact test value $=29.82, \mathrm{P}<0.05$, showed that effective supply chain management reduced significantly total cost which also increased productivity in the organization. This 
has rejected the null hypothesis and accepted the alternate hypothesis that effective uses of lean and agile strategies reduce total cost in the organization.

This is in line with the empirical evidence by Christopher et al (2000) that effective management of supply chain through the use of "lean strategy reduced waste of time, resources and other redundancies that increased total cost and affected productivity. Furthermore Wamaks (1996) affirmed that supply chain which provided incentives for suppliers and other partners to merge their "learning curves (that is share their findings about how to make parts better, cheaper, faster and with less effort) reduced total cost and increased the productivity of the organizations. Ketchen et al (20006) upheld this view as they referred to cost reduction as a competitive priority that reduced price of goods and increased demand which naturally encouraged the manufacturers to increase production. This finding substantiated the strategic theory that encouraged managers to device strategies that will make their organization competitive enough in the market.

\subsection{Objective two}

To determine the extent of relationship between PMEs responsiveness to customers demand, patronage (Sales) and level of inventory in the warehouses of these organizations in, DR Congo. Sequel to the attempt to determine the relationship between PMEs responsiveness to customers demand, patronage (Sales) and inventory level in the warehouses of these organizations, the result to the analysis of the research question revealed that $94.8 \%$ of the respondents agreed that when PMEs respond quickly to customers' demand, there is large increase in patronage (sales and a high reduction in the inventory level in distribution channels (warehouses). The test of the hypothesis-2, using Fisher's exact test value $=133.6, \mathrm{P}$ $<0.05$,revealed that responsiveness to customers' demand is significantly associated with increase in sales and low inventory level in warehouses therefore it means that the null hypothesis was refuted and the alternate hypothesis accepted. This finding was in agreement with Sukati, Hamid, Baharun and Tat (2010) empirical evidence that sensitivity to the ever changing demands of the customers increased their acceptance of the products which increased their patronage (sales), when there is high patronage, there is automatic reduction in inventory level in distribution channels. Christopher cited in Sukati et al (2010) stated that getting the right product at the right price, at the right time to the customers is not only improved competitive success but also the key to survival. Swamidas and Newill (1987) further agreed by stating in their empirical study that manufacturing flexibility which is part of responsiveness to customers demand can appropriately solve problems of sales or high inventory level which have been rocking the manufacturing enterprises. Furthermore, Lee (2004) agreed with this in his argument that with agile strategy, firms exploited profitable opportunities in volatile market place because they reacted quickly to unexpected or rapid shifts in 
customers' demand. Hult et al (2002) also stated that responsiveness which is the ability to detect and fill gaps between what the customer desired and what is currently offered; meeting customers desires guaranteed patronage.

Stevenson and spring (2007) also in agreement with the foregoing stated that responsiveness to customers' demand which gave rise to production in small batches reduced inventory level which was the main bane of mass production. This finding substantiated the Institutional theory that revealed the effect of environmental pressure on organizational activities. The appropriate response by the organization affects their competitiveness.

\section{Conclusion}

This study concluded that effective supply chain management manifested in integration with chain partners, use of lean and agile strategies, high product quality, responsiveness to customers' demand, socio-economic aspects of the partners significantly impacted positively on organizational performance of PMEs which are shown in product availability both in raw materials and finished goods for the target market, cost reduction, low inventory level, few product recalls and better supply chain management. The SCOR model adapted was appropriate for the DR Congo business environment.

\section{Recommendations}

Following the findings of this study, the following recommendations:

Each PME should identify and maintain closer relationship with the key entities they carry out businesses with, especially the suppliers of raw materials and customers by establishing a new vice president or manager in charge of supply chain. These managers will co-ordinate the activities of the focal organization with other organizations to establish a cross- functional team for their products.

The standard organization of DR Congo (SON), National Agency for food, Drug Administration and Control NAFDAC); and other quality control agencies should beef up their quality watch over the goods and services produced in DR Congo and imported into DR Congo by visiting these organizations without notice, combing the market for fake products and confiscating them, using professional bodies to fish out fake products, blacklist and impose sanction where necessary.

As each organization interacts with the key partners in the chain especially the customers, they should produce in small batches to respond quickly to the ever changing demands of the customers. Productions in batches according to the demand of the customers will also reduce the level of inventory stored in distribution channels.

The parent bodies of these enterprises like manufacturers association of DR Congo (MAN), (SMEs), (SMEDAS) among others should periodically organize 
seminars/workshops for the managers of these organizations to sensitize and enlighten them on current business management approaches to aid them flow with the global business trend.

Finally the use of current production strategies like lean and agile system that will both reduce all manner of wastes and create the needed information which will reduce the total cost, increase productivity and market share for the organizations.

\section{References}

Bourne, M. C. S., Mills, J. F., Bicheno J., Hamblin, D. J., Wilcox M. \& Neely A. D. \& Platts, K, W., (1999). Performance Measurement System Design: Testing a Process Approach in Manufacturing Companies. International Journal of Business Performance Measurement, 1(2), 154 - 170.

Chopra, S. \& Meindl, P. (2001). Supply Chain Management; Strategy, Planning, and Operations. Upper Saddle River, New Jersey, Prentice Hall.

Christopher, M. \& Toivil, D.R. (2001). Supply chain migration from lean and functional to agile and customized. International Journal of Supply Chain Management, 5(4), 206-213.

Council of Supply Chain Management Professionals (CSMP) (2011). CSCMP Supply Chain Management Definitions. To access the definitions, gotohttp://cscmp.org/aboutcscmp/ definitions.asp (accessed 02-07-2011)

Cox, A. (1999), Power, value and supply chain management. Supply Chain Management: An International Journal, 4 (4), 167-75.

Cox, J.F., Blackstone, J.H., \& Spencer, M.S. (1995). APICS Dictionary: American Production and Inventory Control Society, Virginia: Falls Church.

Douglas, M, James, R. Stock, \& Lisa, M, Ellram, (1998). Fundamentals of Logistics Management. McGraw-Hill, Chapterl4.

Drucker, P. F. (1998).Management's New Paradigms. Forbes Magazine, October 5, 152-177.

Habib, M. (2011). Supply Chain Management (SCM). Theory and Evolution. Bangladesh: American International University.

Habib, M. (2010). An Empirical Research of ITESCM (Integrated Tertiary Educational Supply Chain Management) Model Editor, Sciyo.com: Management and Services October, ISBN 978-953-307-118-3.

Iroegbu, N. F. (2014). Effect of Competitive Intelligence in small and medium scale enterprises in Abia state. University of DR Congo, Enugu Campus (unpublished seminar paper for Doctor of Philosophy Management). 
Jones, T. \& Riley D.W. (1985). Using inventory for competitive advantage through supply chain management. International Journal of Physical Distribution and Materials Management, 15(5), 16-26.

Kaplan,R.S.\& Norton,D. P.(1992). The Balanced Scorecard- Measures that drive Performance. Harvard Business Review, 70(1), 71-79.

LaLonde, B. J. \& Maters, J. M. (1994). Emerging Logistics Strategies: blueprints for the next century. International Journal of Physical Distribution and Logistics Management, 24(7), 35-47.

Lambert, D.M., Stock J.R., \& Ellram L.M (1998). Fundamentals of logistics management. Boston: Irwin/McGraw-Hill

Lambert, D. (2008). An executive summary of Supply Chain Management: Process, Partnerships, Performance, And Jacksonville: The Hartley Press, Inc.

Lambert, D. M., \& Cooper, M. C. (2000). Issues in Supply Chain Management. Industrial Marketing Management, 29(1) 65-83. http://dx.doi.org/10.1016/S00198501 (99)00113-3

Lambert, D., García-Dastugue, S. \& Croxton, K. (2005).An evaluation of processoriented supply chain management framework. Journal of Business Logistics, 25(1), 25-51.

Lamming, R. C. (1995). Beyond Partnership: Strategies for Innovation and Lean Supply. Hemel Hempstead: Prentice-Hall.

Lee, H. L. (2004). The triple- A supply chain. Harvard Business Review, 82(10): 102-112.

Lummus, R. R. \& Vokurka, R.J. (1999). Defining Supply Chain Management: a Historical perspective and practical guidelines. Industrial Management \& Data Systems, 99 (1), 11-17.

Nasland, D. \& Williamson, S. (2010). What is Management in supply chain Management? - A critical Review of Definitions, Frameworks and Terminology. Journal of Management Policy and Practice, 4, 11-28.

Onodugo, V.A; Ugwuonah, G.E; \& Ebinne, E.S. (2010) Social sciences research: Principles, Methods and Applications. Enugu: EL'DEMAK.

Onugu, N.B.A. (2005). Small and Medium Enterprises (SMEs) in DR Congo: Problems and prospects. St. Clements University, DR Congo (Unpublished Dissertation for PhD in Management Award).Operations Management, 11 (1), 9-20.

Park, A. Nayyar, G., \& Low, P. (2013). Supply chain perspectives and issues: A literature review. Switzerland: Fung Global Institute and world Trade Publication. 
Vokurka, R. and S. O'Leary-Kelly. (1999).A review of empirical research on manufacturing Flexibility. Journal of Operations Management, 18(4), 485-501. 